\title{
Główne determinanty zarządzania etnopolityką w państwach Europy Wschodniej
}

\author{
Magdalena Karolak-Michalska
}

\begin{tabular}{|c|c|}
\hline \multicolumn{2}{|c|}{ A BSTRAKT } \\
\hline \multicolumn{2}{|c|}{$\begin{array}{l}\text { Cel artykułu: Celem artykułu jest identyfikacja i analiza kluczowych determinant - } \\
\text { etnodemograficznych, kulturowych, prawnych, etnopolitycznych i multilateralnych, } \\
\text { kształtujących zarządzanie etnopolityką w państwach Europy Wschodniej (Białorusi, } \\
\text { Mołdawii i Ukrainy). }\end{array}$} \\
\hline \multicolumn{2}{|c|}{$\begin{array}{l}\text { Metodyka badań: Interdyscyplinarne podejście badawcze; metody charakterystyczne } \\
\text { dla nauk o zarządzaniu, o bezpieczeństwie. Zastosowano m.in. analizę systemową, } \\
\text { metodę instytucjonalno-prawną, porównawczą, behawioralną, etnopolityczną, etno- } \\
\text { demograficzną. Wykorzystano wnioski z obserwacji własnych z wyjazdów zagranicz- } \\
\text { nych w latach 2014-2018. }\end{array}$} \\
\hline \multicolumn{2}{|c|}{$\begin{array}{l}\text { Wyniki: Pomijanie determinant etnodemograficznych, kulturowych, prawnych, etno- } \\
\text { politycznych, multilateralnych utrudnia skuteczne zarządzanie etnopolityką na Biało- } \\
\text { rusi, w Mołdawii i na Ukrainie. Nie uwzględnianie przez władze państwowe powyższych } \\
\text { uwarunkowań w formułowaniu celów etnopolityki rzutuję na brak jej skuteczności, } \\
\text { sprzyja konfliktom etnicznym, zagrażając bezpieczeństwu państw subregionu. }\end{array}$} \\
\hline \multicolumn{2}{|c|}{$\begin{array}{l}\text { Wkład i wartość dodana: Poszerzenie badań nad uwarunkowaniami zarządzania etno- } \\
\text { polityką; artykuł ma charakter interdyscyplinarny, ma rolę poszerzającą perspektywę } \\
\text { postrzegania Białorusi, Mołdawii i Ukrainy w kontekście zarządzania procesami etno- } \\
\text { politycznymi, a także potencjalnych inwestycji, ich skali i rodzaju. Znajomość badanych } \\
\text { uwarunkowań może być kluczowa przy podejmowaniu decyzji o angażowaniu środków } \\
\text { finansowych w tych państwach. }\end{array}$} \\
\hline & \\
\hline & \\
\hline & \\
\hline & \\
\hline
\end{tabular}

\section{Sugerowane cytowanie:}

Karolak-Michalska, M. (2019). Główne determinanty zarządzania etnopolityką w państwach Europy Wschodniej. International Entrepreneurship Review (previously published as International Entrepreneurship / Przedsiębiorczość Międzynarodowa), 5(1), 93-105. https://doi.org/10.15678/IER.2019.0501.06 


\section{WPROWADZENIE}

Postępujące przeobrażenia w subregionie Europy Wschodniej (na Białorusi, w Mołdawii, na Ukrainie), mające miejsce głównie na terytorium ukraińskim i mołdawskim stawiają coraz więcej pytań o kondycję etnopolityki Mołdawii i Ukrainy. Widać wyraźnie, że żadne z państw nie jest w stanie w sposób długofalowy zapobiegać konfliktom narodowościowym, niejako sankcjonując już istniejące podziały językowe, tożsamościowe, czy polityczne, a co szczególnie ważne, generując także nowe. Pytanie o to, jak zarządzać etnopolityką, aby ta nie generowała niepotrzebnych podziałów rzutujących na bezpieczeństwo państwa, w tym społeczne i ekonomiczne, staje się przedmiotem coraz większej liczby dyskusji i debat publicznych, a także stanowi płaszczyznę analiz dla naukowców. Dodać należy, że subregion ze względu na położenie geograficzne, zróżnicowanie kulturowe i etniczne, przy jednoczesnym ścieraniu się na jego obszarze wpływów Federacji Rosyjskiej i Unii Europejskiej, jest obszarem podatnym na występowanie wielorakich procesów etnpolitycznych, a także konfrontacji, które mogą i przybierają wymiar konfliktów etnopolitycznych zagrażających jego bezpieczeństwu. Od lat utrzymująca się sytuacja transformacji polityczno-gospodarczej badanych państw, patologie, korupcja, paraliż wymiaru sprawiedliwości charakterystyczny zarówno dla Białorusi, Mołdawii, jak i Ukrainy, a także trwająca od 5 lat wojna w Donbasie, która jako jeden ze scenariuszy zakończenia przybiera postać federalizacji Ukrainy, czy też kwestia separatystycznego Naddniestrza, potwierdzają, że istniejące reżimy są kryzysogenne.

W tak kształtującej się rzeczywistości społeczno-politycznej, zasadne jest poszerzanie wiedzy o jej uwarunkowaniach. Celem niniejszego artykułu jest identyfikacja i analiza kluczowych determinant - etnodemograficznych, kulturowych, prawnych, etnopolitycznych i multilateralnych, kształtujących zarządzanie etnopolityką w państwach Europy Wschodniej (Białorusi, Mołdawii i Ukrainy). Autorka dokonując badań niniejszej problematyki stawia dwa główne pytania badawcze:

1. Jak rozumiana jest etnopolityka w państwach subregionu?

2. Czynniki o jakim charakterze kształtują działania podejmowane przez władze państwowe poszczególnych państw (Białorusi, Mołdawii, Ukrainy) w zakresie zarządzania etnopolityką?

Realizacja powyższego celu ma miejsce w oparciu o zastosowanie katalogu metod badawczych, w tym szczegółowo, w badaniach zastosowanie znajdują głównie następujące metody: 1) analiza systemowa, dzięki zastosowaniu której badana rzeczywistość podlega interpretacji nie jako luźny zbiór izolowanych elementów, lecz jako „przestrzeń” wewnętrznie zintegrowana i kierująca się prawidłowościami; 2) metoda instytucjonalnoprawna; 3) metoda porównawcza, dająca możliwość określenia elementów wspólnych i odmiennych w podlegających procesom transformacji państwach w zakresie zmian systemu politycznego, prawnego, gospodarczego i społecznego; 4) metoda historyczna; 5) metoda behawioralna, umożliwiające analizę zjawisk społecznych w drodze obserwacji zachowań tak jednostek, jak i zbiorowości ludzkich; 6) metoda etnopolityczna, której przedmiotem analizy jest partycypacja wspólnot etnicznych w strukturach władzy, zależność między strukturą etniczną państwa bądź regionu i etniczną reprezentacją w ustawodawczych i wykonawczych organach władzy; 7) metoda etnodemograficzna, analizuje podstawowe wskaźniki demograficzne wspólnot etnicznych. 


\section{ROZUMIENIE ETNOPOLITYKI W PAŃSTWACH SUBREGIONU}

W państwach Europy Wschodniej ${ }^{1}$ etnopolityka nabiera szczególnego znaczenia, odnosząc się do relacji między etnicznością i polityką ${ }^{2}$. To oddziaływanie elit władzy reprezentujących państwo na grupy etniczne, których elity polityczne dokonują „wewnętrznej” weryfikacji państwowej etnopolityki, oraz wzajemne relacje między samymi grupami etnicznymi. Kluczowe dla analizy są więc trzy kategorie z zakresu etnopolityki, które możemy potraktować jako jej podmioty: 1) państwo; 2) elity polityczne reprezentujące, z jednej strony, państwo i, z drugiej - grupy etniczne; 3) grupy etniczne (Wierzbicki, 2015). W ujęciu przedmiotowym etnopolityka, jako działalność praktyczna, składa się z trzech, współzależnych komponentów: 1) etniczności - urzeczywistnianej przez wspólnoty etniczne w polityce i życiu społecznym; 2) organizmów etnopolitycznych - obejmujących całokształt form organizacji życia społecznego i ich instytucji politycznych, w tym norm prawnych i politycznych, a także - ukształtowanych tradycją i zwyczajami - instytucji etnospołecznych; 3) procesów etnopolitycznych - obejmujących reprezentację polityczną wspólnot etnicznych w organach władzy, ich partycypację w zarządzaniu państwem i zachowania polityczne, działalność etnicznych organizacji społeczno-politycznych, procesy narodotwórcze, kwestię językową (Wierzbicki, 2008).

Badania nad definicyjnym ujęciem etnopolityki ujawniają również katalog jej celów. Wśród najczęściej widocznych w badaniach i analizach eksperckich sytuują się: a) umożli-

\footnotetext{
${ }^{1}$ Białoruś, Mołdawia i Ukraina tworzące państwa Europy Wschodniej łącznie zajmują obszar 845,1 tys. km² ${ }^{2}$ który zgodnie z danymi z pierwszej połowy 2019 roku zamieszkuje ok. 54,5 mln ludzi różnych narodowości. Każde z tych państw oprócz charakterystycznej dla siebie mozaiki etnicznej, odznacza się także specyfiką geograficzną, kulturową, gospodarczą i polityczną. Doprecyzować należy, że państwa te tworzą element szerszego obszaru określanego mianem Europy Środkowo-Wschodniej - przestrzeni identyfikowanej na gruncie geopolityki i stosunków międzynarodowych, w skład której w holistycznym i jednocześnie najszerszym ujęciu koncepcyjnym wchodzą: 1) państwa grupy Wyszehradzkiej (Polska, Czechy, Słowacja, Węgry); 2) państwa nadbałtyckie (Litwa, Łotwa, Estonia); 3) Białoruś, Ukraina, Mołdawia; 4) państwa powstałe z rozpadu dawnej Jugosławii (Słowenia, Chorwacja, Bośnia i Hercegowina, Czarnogóra, Macedonia, Serbia, Kosowo); 5) pozostałe kraje bałkańskie (Albania, Bułgaria, Rumunia) (Zenderowski, Chałupczak, Baluk, 2015).

${ }^{2} \mathrm{~W}$ języku polskim - jak podkreślają profesorowie Zenderowski, Chałupczak, Baluk - używa się pojęć „polityka etniczna" (termin używany częściej współcześnie, w odniesieniu do obecnych stosunków etnicznych i narodowościowych) lub „polityka narodowościowa” (termin częściej używany do kwestii historycznych). Na gruncie polskim używany jest także termin „etnopolityka”. Można przyjąć, że w języku polskim pojęcia te są tożsame. Z punktu widzenia obszaru geograficznego podejmowanej problematyki kluczowe jest w powyższym kontekście odniesienie się do języka rosyjskiego, w którym لffunkcjonują terminy: „этнополитика” („etnopolitika"), „национальная политика" („nacional'naâ politika”). Terminy te stosowane są wymiennie. Własne analizy występowania badanego pojęcia, pozwalają zgodzić się z badaczami (Chałupczak, Zenderowski, Baluk), że w dostępnych słownikach politologicznych, lingwistycznych, filozoficznych, jeżeli podaje się definicję роје̨cia „этнополитика”, to nie ma definicji роје̨сіа „национальная политика” (i odwrotnie). Doprecyzować należy, że w większym stopniu termin "этнополитика" używany jest w literaturze naukowej, podczas gdy роје̨сіе „национальная политика” dominuje w dokumentach urzędowych (np. ustawy). Z kolei w języku ukraińskim termin „національна політика” („,nacionalna polityka”), jest bardziej popularny od terminów „етнополітика” („etnopolityka”) i „etniчna політика” („etniczna polityka”). Z analizy literatury ukraińskiej wynika, że występuje zamienne stosowanie роје̨ć „національна політика” і „етнополітика”. Zwraca uwagę, że „роје̨сіе „національна політика” znacznie częściej używane jest w aktach prawnych państwa, a pojęcie „етнополітика” w pracach o charakterze badawczo-naukowym. Na Ukrainie widać tendencję do łączenia tych określeń w ramach polityki etniczno-narodowościowej („етнонаціональна політика"). Takie sformułowanie pojawia się w oficjalnych dokumentach i materialach. W języku ukraińskim można mówić o neutralnym charakterze definicji „етнополітика”, со ciekawe, terminem tym niektórzy autorzy nazywają naukę, podkreślając jej związek ze środowiskiem naukowym (Zenderowski, Chałupczak, Baluk, 2015).
} 
wianie pełnej partycypacji politycznej poszczególnych grup etnicznych w systemie politycznym danego państw (Jansons, 2003; Wierzbicki, 2008); b) tworzenie warunków do współpracy między poszczególnymi grupami etnicznym (Toščcenko, 1993); c) regulowanie stosunków między grupami etnicznymi (Abdulatipov, 2004); d) uzgadnianie i harmonizacja interesów - polityka etniczna jako „realizacja interesów każdej wspólnoty etnicznej, uwzględniajqc specyfikę ich mentalności, sposobu życia, historii, dziedzictwa kulturowego niezależnie od liczebności oraz zwartego bqdź rozproszonego zamieszkania" (Guboglo, 2003, s. 723); e) zapobieganie i rozwiązywanie konfliktów etnicznych, ochrona mniejszości, utrwalanie tolerancji międzyetnicznej (Kellas, 1998; Tavadov, 2004); f) zaspokojenie potrzeb i aspiracji poszczególnych grup etnicznych; g) tworzenie warunków do rozwoju i podtrzymywania tożsamości narodowych, a także odrodzenia narodowego, np. po okresie przymusowej asymilacji (Guboglo, 2003); h) promowanie i utrzymywanie jedności (integralności) społecznej i politycznej państwa (suwerenność) oraz poszczególnych grup etnicznych (Guboglo, 2003); i) integracja i asymilacja członków poszczególnych grup etnicznych z narodem większościowym/tytularnym (Rothschild, 1981).

Etnopolityka w literaturze przedstawiana jest w kategoriach dążenia do: 1) zachowania lub umocnienia uprzywilejowanej pozycji narodu tytularnego kosztem innych grup etnicznych i narodów; 2) postępującej planowej i zorganizowanej marginalizacji społecznej, kulturowej, społecznej i ekonomicznej grup mniejszościowych lub świadomego ignorowania potrzeb lub interesów mniejszości; 3) eliminacji mniejszości (poprzez asymilację, wysiedlenia, wypędzenia) (Zenderowski, Chałupczak, Baluk, 2015). Ponadto, jak pisze Daniel N. Posner, „na politykę etnicznq można patrzeć w kategoriach polityki budowania koalicji, a wybór tożsamości etnicznej można widzieć w kategoriach dqżenia do członkostwa w koalicji, która będzie najbardziej politycznie i gospodarczo użyteczna" (Posner, 2005, s. 2).

Zarządzanie etnopolityką łączy się także z funkcjami społecznymi. Do najważniejszych należy zaliczyć: 1) funkcję ochronną (ochrona danego status quo, ochrona tożsamości i stanu posiadania narodu tytularnego, ochrona praw mniejszości itp.); 2) funkcję integracyjną (integracja członków narodu tytularnego, w tym tzw. nation-building; utrzymanie więzi z rodakami mieszkającymi na stałe lub tymczasowo za granicą; integrowanie członków mniejszości, wytwarzanie i utrwalanie spójności społecznej w wymiarze ponadetnicznym); 3) funkcję dystrybucyjną (w wymiarze materialnym i niematerialnym) - umożliwia ośrodkowi władzy dystrybuowanie ograniczonych zasobów między poszczególne grupy etniczne/narodowe, dzięki czemu w istotny sposób wpływa na postawy społeczno-polityczne członków poszczególnych grup; 4) funkcję regulacyjną (tworzenie procedur i instytucji definiujących relacje między władzą publiczną a poszczególnymi grupami etnicznymi; definiowanie przysługujących ich członkom praw i obowiązków wobec państwa; definiowanie obowiązków państwa wobec mniejszości); 5) funkcję konfliktotwórczą (wytwarzanie i zarządzanie konfliktami społecznymi o podłożu etnicznym jest jedną z form utrwalania i utrzymania władzy politycznej; polega to najczęściej na wytwarzaniu w danej grupie zwykle narodzie tytularnym poczucia zagrożenia ze strony innej grupy etnicznej i na ustawieniu się w roli obrońcy); 6) funkcję edukacyjno-propagandową (generowanie wiedzy na temat narodu i grup etnicznych oraz zachęcanie do przyjmowanie określonego typu postaw wobec nich); 7) funkcję komunikacyjną (tworzenie oficjalnych i nieoficjalnych kanałów symetrycznej lub asymetrycznej, wertykalnej i horyzontalnej komunikacji między pod- 
miotami polityki etnicznej: władzami, mniejszościami, imigrantami, diasporą itd.,); 8) funkcję mobilizacyjną (tworzenie systemu zachęt do bardziej aktywnej partycypacji w życiu społeczno-politycznym, w tym w procesie umacniania więzi etnicznych, działania na rzecz spójności narodowej) (Zenderowski, Chałupczak, Baluk, 2015).

\section{GŁÓWNE DETARMIANTY ZARZĄDZANIA ETNOPOLITYKA}

Podejmując próby poszukiwania determiant kształtujących współczesną etnopolitykę państw subregionu, trzeba zauważyć, że mają one różnorodny charakter, dotyczący wielorakich przestrzeni, w tym demograicznej, kulturowej, tożsamościowej, prawnej, a także politycznej. Co szczególnie ważne, zarówno na Białorusi, w Mołdawii, jak i na Ukrainie uwarunkowania te posiadają swoją specyfikę, rzutując na cały proces zarządzania etnopolityką w wskazanych państwach.

Dostępne analizy i badania własne wskazują, że jednym z głównych i niejako determinujących zarządzanie etnopolityką w państwach Europy Wschodniej jest uwarunkowanie etnodemograficzne danego państwa, będące najczęściej wynikiem kompilacji czynników historycznych, gospodarczych, politycznych i kulturowych. Istotną rolę w ramach struktury demograficznej odgrywa korelacja pomiędzy liczebnością narodu tytularnego i narodów nietytularnych (mniejszości narodowych i etnicznych) żyjący w jednym państwie. W latach 1991-2019 zarówno na Białorusi, Mołdawii, jak i Ukrainie podstawę tamtejszej struktury narodowościowej tworzy naród tytularny, nie ustępując miejsca żadnej z mniejszości narodowych i etnicznych (według spisów narodowych przeprowadzonych w badanych państwach narody tytularne stanowiły odpowiednio: 1) Białoruś - w 1999 roku Białorusini stanowili 81,23\%, w 2009 roku - 83,4\%; 2) Mołdawia - w 2004 roku Mołdawianie stanowili 79,1\%, w 2014 roku 75,1\%; 3) Ukraina - w 2001 roku Ukraińcy stanowili 77,8\%). Na tle subregionu szczególną uwagę zwraca pozycja demograficzna mniejszości rosyjskiej, która wg. danych na 2019 rok stanowi 8,3\% ludności Białorusi, 4,1\% Mołdawii (bez Naddniestrza, gdzie Rosjanie stanowią około 30\% tamtejszej struktury etnicznej) i 17,3\% struktury Ukrainy (Nacional'nyj statičeskij, 2019; Nacional'nyj sostav naseleniâ Ukrainy, 2001; Nacional'nyj sostav naseleniâ, 2009; Recensamant, 2014). Dodać należy, że w przypadku zróżnicowania etnicznego ważną rolę odgrywają także migracje ludności w subregionie. Procesy migracyjne stanowią odbicie zachodzących przeobrażeń w sferze kulturalnej, gospodarczej i politycznej. Określone trendy zmian ludnościowych mają siłę kreowania zmian społecznych, dlatego też muszą być obserwowane i analizowane, aby można było w odpowiednim czasie podjąć działania interwencyjne - umiejętnie zarządzać falami migracyjnymi. Przykładowo, w przypadku Ukrainy wobec $2 \mathrm{mln}$. fali migracji na skutek m.in. wojny w Donbasie, państwo to weszło w fazę zmian społeczno-politycznych, które przynoszą określone konsekwencje dla bezpieczeństwa społecznego, w tym ograniczenie zdolności obronnych państwa.

W przypadku uwarunkowań kulturowych uwagę zwraca poczucie tożsamości narodowej społeczeństw państw subregionu. Bezspornym staje się, że wśród ukraińskiego społeczeństwa faktycznie obecne są istotne różnice w treści tożsamości narodowej, co jest podyktowane m.in. dużymi wpływami kultury rosyjskiej, w tym głównie języka rosyjskiego, który od 1991 roku jest obecny na terenie Ukrainy, ale także i na całej przestrzeni poradzieckiej. Hnatiuk jest zdania, że „narodu tego nie jednoczy ani wspólny język, ani wspólna pamięć historyczna, ani też wyzwanie - trzy elementy uważane za konstytutywne dla tożsamości narodowej” (Hnatiuk, 2003, s. 56). Dodać należy, że odmienności w postrzeganiu 
tego czym jest tożsamość ukraińska niejednokrotnie są tak silne spolaryzowane - co pokazują wydarzenia wojny w Donbasie - że uniemożliwiają prawidłowe funkcjonowania państwa. Z kolei proces kształtowania się tożsamości narodowej społeczeństwa białoruskiego - podobnie, jak i ukraińskiego - przebiega w sposób skomplikowany i niejednoznaczny. Większość Białorusinów czuje się związana z Rosją. Przeciętny Białorusin, odbiera swoją białoruskość w kategoriach folklorystyczno-etnograficzno-językowej regionalnej odrębności w ramach większej całości, którą tworzą razem z Rosjanami i porównują się z nimi, a nie z Zachodem (Radzik, 2009). W kontekście państwowo-terytorialnym Białorusini określają się jako белорусы, ale jeśli chodzi o przynależność kulturową określają się jako Русские. Natomiast w przypadku Mołdawii charakterystycznym jest to, że w społeczeństwie mołdawskim na przestrzeni lat wykształciły się dwa główne modele tożsamości: panrumunizm (ze względu na naród) i mołdawianizm (ze względu na etniczność). Istniejącym modelem jest także panslowianizm³.

Rozważając o uwarunkowaniach kulturowych w procesie zarządzania etnopolityką trzeba również odnieść się do statusu języka państwowego (na Białorusi są to języki białoruski i rosyjski, w Mołdawii mołdawski, na Ukrainie - język ukraiński), a także pozycji języków mniejszości narodowych i etnicznych (Wierzbicki, 2014). Zwraca uwagę, że kwestia statusu języka mniejszości narodowych staje się niejednokrotnie przedmiotem sporów, prowadząc z jednej strony do konfliktów na tle etnicznym, z drugiej generując podziały wśród społeczeństwa. Przykładowo, sytuacja ta w praktyce dotyczy na Ukrainie statusu języka rosyjskiego (ludność rosyjska od 1991 roku zgłasza postulaty związane z nadaniem językowi statusu równorzędnego z językiem państwowym), a także języka węgierskiego (mniejszość węgierska żyjąca na Zakarpaciu dąży do przyznania autonomii kulturalnej dla rejonu, a także uznania języka węgierskiego za regionalny).

Kolejną płaszczyzną uwarunkowań są determinanty prawne. Dotyczą one ustawodawstwa wewnętrznego i zewnętrznego państw subregionu w zakresie zapewnienia praw mniejszości narodowych i etnicznych. Poddając analizie akty prawne państw Europy Wschodniej odnoszące się do etnopolityki (konstytucje Białorusi, Mołdowy i Ukrainy, a także ustawy i akty prawne niższego rzędu), widać wyraźnie, że zawierają one podstawowe gwarancje w zakresie praw mniejszości narodowych i etnicznych, w tym przynależność do mniejszości traktują jako sprawę indywidualnego wyboru każdego obywatela. Co szczególnie ważne, w ustawodawstwie badanych państw regulacje dotyczące praw mniejszości narodowych i etnicznych nie są ani rozbudowane, ani zbyt szczegółowe. $Z$ jednej strony wieloetniczność państwa (szczególnie na Ukrainie) przyczyniła się do stworzenia bazy ustawodawczej związanej z mniejszościami narodowymi, z drugiej nie ustrzegła się wady braku przedstawicielstwa mniejszości w mechanizmie wyznaczania zakresów, dystrybucji i kontrolowania wykorzystania środków budżetu państwa przeznaczonych na potrzeby mniejszości (Shypka, 2015).

Dla mniejszości narodowych i etnicznych w państwach Europy Wschodniej szczególnego znaczenia nabiera respektowanie jej praw w życiu codziennym (Jakubowski, 2018). Z obserwacji sceny politycznej Białorusi, Mołdowy, Ukrainy i prowadzonej przez ich władze

\footnotetext{
${ }^{3}$ Pansłowianizm był silnie akcentowany w latach 1940-1989. Propagowany przez komunistów związanych z utworzeniem Mołdawskiej Socjalistycznej Republiki Radzieckiej. Założeniem była integracja mieszkańców Mołdawii z ludnością Związku Radzieckiego. Ten rodzaj tożsamości widoczny jest współcześnie w Naddniestrzu (Wierzbicki, 2014).
} 
polityki narodowościowej wynika, że teoretycznie najtrudniejsza sytuacja w kwestii respektowania praw mniejszości narodowych powinna występować na Białorusi - co koresponduje $z$ autorytarnym charakterem tamtejszego reżimu politycznego. W opinii większości badaczy prawa te są naruszane poza mniejszością rosyjską (Miazga, Dybcio, 2001). Ponadto, w polityce władz białoruskich wyraźna jest tendencja naruszania praw tych mniejszości, które są wykorzystywane przez ich historyczne ojczyzny do ingerencji w wewnętrzne sprawy Białorusi i zmianę władzy.

W państwach Europy Wschodniej istnieje potrzeba podjęcia działań legislacyjnych odnoszących się do respektowania praw mniejszości narodowych. Polityka narodowościowa władz Białorusi, Mołdowy i Ukrainy powinna nade wszystko skoncentrować się na porozumieniu międzyetnicznym i zapobieganiu konfliktom etnicznym na ich terytoriach, a także zagwarantowaniu harmonijnego rozwoju stosunków między narodem tytularnym i mniejszościami narodowymi. Ponadto powinna skupić się wokół demokratyzacji i poprawy warunków życia, a także aktywizacji wszystkich grup w budowie społeczeństwa obywatelskiego oraz zagwarantowania ochrony tożsamości etniczno-kulturowej mieszkańców Białorusi, Mołdowy i Ukrainy (Wierzbicki, Karolak-Michalska, 2016).

Kolejną płaszczyzną uwarunkowań zarządzania etnopolityki stanowią determinanty etnopolityczne, związane z udziałem reprezentantów mniejszości narodowych w strukturach władzy, a także z ich aktywnością w ramach partii politycznych i organizacji pozarządowych. Nadmienić trzeba, że procesy etnopolityczne w państwach subregionu korespondują z transformacją systemów politycznych państw poradzieckich, a ta z kolei (jak już niejednokrotnie wskazywano $w$ literaturze przedmiotu) jest podyktowana szerokim katalogiem czynników (np. istnienie lub brak silnej tradycji państwowości, odmienności struktury społecznej, stosunek elit władzy do procesu transformacji, kondycja ekonomiczna państwa i jego powiązania gospodarcze z państwami ościennymi, czy w końcu przynależność do odmiennych kręgów kulturowych) (Bodio, Jakubowski, 2010).

W państwach subregionu w strukturach władzy ustawodawczej w latach 1991-2019 przeważał naród tytularny (odpowiednio ukraiński, białoruski, mołdawski). W badanym okresie w żadnym z analizowanych państw nie wprowadzono także ograniczenia dostępu innym grupom narodowym czy etnicznym do udziału we władzy. Reprezentanci mniejszości mogą uczestniczyć w procesie państwotwórczym, zachodzącym odpowiednio na Białorusi, Mołdawii czy Ukrainie.

Badając kwestię reprezentacji mniejszości narodowych i etnicznych w organach władzy w latach 1991-2019 widać wyraźnie, że Mołdawianie, Białorusini, Ukraińcy formalnie zapewniają sobie uprzywilejowane położenie w organach władzy, nie gwarantując „zarezerwowanych" miejsc mniejszościom. Ponadto brak regulacji prawnej reprezentacji narodowości w poszczególnych szczeblach władzy jest swoistą „promocją” narodu tytularnego w elitach władzy państwowej (Bodio, 2010).

Kluczowym czynnikiem pobudzającym aktywność mniejszości narodowych i etnicznych w państwach Europy Wschodniej są przemiany społeczno-polityczne, jakie dokonują się w tych państwach od 1991 roku (Kubaczyk, Majchrzak, Żyła, 2018). Nowe warunki - podlegające ciągłej zmianie - dają przestrzeń do działań społeczności etnicznych, a te od lat 90. XX wieku skupione były i są nadal wokół kwestii odrodzenia czy ożywienia etnicznych kultur. Wraz z dynamiką przemian społeczno-gospodarczych w subregionie aktywność mniejszości narodowych nabiera przemyślanego charakteru. Znajduje to swój wyraz między innymi 
w postępujących procesach samoorganizowania się mniejszości w związki, stowarzyszenia czy organizacje. Ponadto, ujawnia zmagania wśród danych wspólnot etnicznych w wymiarze nabywania przez ich członków świadomości politycznej, budowania poczucia podmiotowości, ale też samoorganizowania się i rozwiązywania wewnętrznych sporów.

Ostatnie z kluczowych determinant zarządzania etnopolityką stanowi płaszczyzna mulilateralna. Jej kwintesencją są stosunki między państwami macierzystymi narodów nietytularnych a państwami przyjmującymi. Na tle subregionu szczególnie ważne w powyższym kontekście są relacje Białorusi, Mołdawii i Ukrainy z Rosją. O ile w przypadku Białorusi, mniejszość rosyjska nie stanowi przedmiotu napięcia czy generowania konfliktu w relacjach białorusko-rosyjskich, o tyle sytuacja ta wygląda odmiennie w przypadku mołdawski i ukraińskim. Na relacjach mołdawsko-rosyjskich ciąży w sposób szczególny kwestia separatystycznego Naddniestrza, co prawda „zamrożonego konfliktu”, ale bezpośrednio związanego z mniejszości rosyjską. Warto nadmienić, że w optyce rosyjskiej Naddniestrze to obszar graniczny oddziaływania russkiego mira, do którego przynależność jest akceptowana przez władze separatystycznego regionu. Naddniestrze stanowi w Europie Wschodniej obszar, w którym wykorzystanie przez Federację Rosyjską pretekstu ochrony mniejszości rosyjskiej i ludności rosyjskojęzycznej, może znacząco przełożyć się na bezpieczeństwo subregionu. Pamiętać należy, że Rosja stara się przeforsować wariant federacyjny, w którym prawobrzeżna Mołdawia wraz z Naddniestrzem oraz - opcjonalnie - z Gagauzją utworzyłyby wspólne państwo. Rozwiązanie to w postaci państwa prorosyjskiego z punktu widzenia władz rosyjskich przyniosłoby szereg korzyści - wywierając wpływ na działania rządu mołdawskiego, głównie w sferze polityki zagranicznej. Wymownym jest, że mieszkańcy obydwu regionów, jak i ich władze są stanowczo przeciwni integracji Mołdawii z UE czy NATO, opowiadając się za współpracą z Rosją, w tym za wstąpieniem do Eurazjatyckiej Unii Gospodarczej (Całus, 2016).

Z kolei w przypadku relacji ukraińsko-rosyjskich sytuacja ta dotyczy aneksji krymskiej, a także trwającej wojny w Donbasie. Chociaż bezpośrednim powodem oderwania się Krymu od Ukrainy miał być w optyce władz rosyjskich przewrót państwowy, do jakiego doszło 22 lutego 2014 roku w Kijowie, uznawany jako jedna z „kolorowych rewolucji” na obszarze poradzieckim, to niezależni badacze i eksperci nie pomijają roli mniejszości rosyjskiej i jej aktywności w procesie włączenia półwyspu do Rosji (Bajor, 2014). Dodać należy, że mniejszość rosyjska jest także uwikłana w retorykę wojny ukraińsko-rosyjskiej toczącej się od 2014 roku w Donbasie. Sukces aneksji Krymu zachęcił rosyjskojęzyczną część społeczeństwa - głównie tworzącą skupiska we wschodniej części państwa - do dalszej aktywności na rzecz secesji. W wielu miastach (szczególnie w regionie wschodnim i południowym - np. Donieck, Ługańsk, Charków) dochodziło do demonstracji i protestów wobec władz ukraińskich, w trakcie których prorosyjscy aktywiści żądali przyłączenia poszczególnych obwodów do FR.

\section{PODSUMOWANIE}

Dokonując ogólnego podsumowania powyższych rozważań, można zauważyć, że prezentowane determinanty - co oczywiste - nie wyczerpują katalogu złożonej rzeczywistości społeczno-politycznej warunkującej efektywne zarządzanie etnopolityką w państwach Europy Wschodniej. Stanowią natomiast „szkielet” czynników, bez uwzględnienia którego trudno o skuteczne planowanie, organizowanie i kontrolowanie procesów etnopolitycz- 
nych. Ewentualne „pomijanie” przez władze państwowe w subregionie powyższych determinant $w$ toku formułowania celów etnopolityki rzutuje $z$ jednej strony na brak skuteczności polityki etnicznej, z drugiej sprzyja powstawaniu napięć i konfliktów na tle etnicznym, tym samym zagrażając bezpieczeństwu poszczególnych państw (szczególnie Mołdawii i Ukrainy), a w konsekwencji całemu subregionowi.

Złożona mozaika uwarunkowań etnopolityki charakterystyczna dla danego państwa subregionu (odpowiednio Białorusi, Mołdawii, Ukrainy) powinna być brana pod uwagę w procesie jej zarządzania, jeśli ma on mieć charakter efektywny. Zarówno determinanty etnodemograficzne, etnokulturowe, prawne, etnopolityczne i multilateralne powinny być uwzględniane przy całym procesie zarządzania etnopolityką, zarówno w ramach funkcji planowania (formułowanie celów państw w zakresie etnopolityki oraz określenie sposobów ich osiągnięcia i niezbędnych zasobów), organizowania (zapewnienie niezbędnych zasobów i uporządkowanie procesu w przestrzeni i czasie, w tym budowa struktury organizacyjnej), motywowania (wyjaśnianie celów działalności oraz pobudzanie wykonawców do ich wykonania) i kontroli (porównanie efektów z zamierzeniami oraz czynności regulujące służące eliminowaniu odchyleń od planu, z możliwością modyfikacji ustalonych celów). Skuteczne zarządzanie etnopolityką bez dogłębnej analizy jej uwarunkowań wydaje się zadaniem niezwykle trudnym.

W końcu, w kontekście przedsiębiorczości międzynarodowej, dodać należy, że znajomość powyższych uwarunkowań rzutuje na decyzje inwestorów, skalę i rodzaj inwestycji, a także daje szereg informacji o kondycji systemu politycznego $\mathrm{w}$ danym państwie subregionu, szczególnie sposobie tworzenia prawa, a także jego jakości, co jest niezwykle cenną wiedzą dla potencjalnych inwestorów. Skuteczna etnopolityka w państwach wielonarodowych łączy się z zapewnieniem bezpieczeństwa, a to z kolei stwarza dogodną przestrzeń dla rozwoju przedsiębiorczości.

W zakresie rekomendacji dotyczących zarządzania etnopolityką w państwach Europy Wschodniej - Białorusi, Mołdawii i Ukrainy, w kontekście planowania szczególnie istotne wydaje się, aby dokonać szczegółowych analiz dotyczących złożoności sytuacji etnicznej w danym państwie (Białorusi, Mołdawii i Ukrainy), w tym demograficznej, kulturowej, a także prawnej. Analiz wymaga także aktywność społeczno-polityczna mniejszości narodowych i etnicznych (głównie mniejszości rosyjskiej, jako najsilniejszej demograficznie i kulturowo w badanych państwach subregionu). W kontekście organizowania rekomenduje się, aby zasoby ludzkie realizujące zadania etnopolityki były zorientowane na zoptymalizowane rozwiązania dotyczące kwestii etnopolitycznej, a nie prowadziły politykę własnych interesów - co jest charakterystyczne dla państw przestrzeni poradzieckiej. Natomiast z punku widzenia funkcji kontroli, podczas procesu zarządzania etnopolityką w państwach Europy Wschodniej kluczowa wydaje się być kwestia całościowego monitoringu sytuacji etnicznej w państwie (odpowiednio na Białorusi, w Mołdawii i na Ukrainie) i ich wpływu na bezpieczeństwo społeczne, polityczne i ekonomiczne w subregionie.

Ważnym jest, aby pamiętać, że każde z uwarunkowań (etnodemograficzne, etnokulturowe, prawne, etnopolitycze czy multilateralne) wywierając wpływ pozytywny (np. możliwość poznania innych kultur, tradycji i języków; rozwój ustawodawstwa w zakresie ochrony praw mniejszości narodowych czy etnicznych) czy negatywny (np. zróżnicowanie etniczne generuje konflikty narodowościowe; dyskryminacja ze względu na pochodzenie etniczne; brak dostosowania ustawodawstwa do sytuacji etnicznej w państwie) swoją siłę 
oddziaływania kieruje wielowymiarowo, w tym wobec mniejszości, wobec narodu tytularnego, wobec państwa, wobec bezpieczeństwa państwa, w końcu wobec bezpieczeństwa całego subregionu (Białoruś, Mołdawia, Ukraina). Przy czym poczucie wagi wpływu danego uwarunkowania szczególnie wobec mniejszości i narodu tytularnego będzie łączyć się z subiektywizmem, niejednokrotnie utrudniając kompleksowe i neutralne budowanie ocen wpływu uwarunkowań etnopolityki na życie obywateli danego państwa (odpowiednio społeczeństwa białoruskiego, mołdawskiego i ukraińskiego).

Istotną kwestią odnoszącą się do etnopolityki badanych państw subregionu jest również jej rozwój. Wydarzenia aneksji krymskiej i wojny w Donbasie wskazują na konieczność redefinicji dotychczasowego zarządzania etnopolityką w państwach subregionu, gdzie już od wielu lat występującym problemem jest kwestia systemowości i spójności działań. W państwach Europy Wschodniej nie nastąpiło jeszcze wyspecyfikowanie procesów projektowania i wykonywania polityki etnicznej. Obecnie procedura ich tworzenia ogranicza się w znacznym stopniu do procesu stanowienia prawa.

Państwa subregionu powinny wypracowywać coraz skuteczniejsze narzędzia służące rozwiązywaniu współczesnych problemów etnopolitycznych, szczególnie związanych $z$ tendencjami separatystycznymi. Istnieje potrzeba bezstronnej i profesjonalnej koordynacji oraz współpracy instytucji. Część z nich powinna odbywać się poprzez zastosowanie zupełnie oddolnych mechanizmów, a część poprzez odwołanie się do form zinstytucjonalizowanych na poziomie państwa. Kluczowym dla efektywności zarządzania etnopolityką w poszczególnych państwach jest to, aby była realizowana za pomocą katalogu dedykowanych narzędzi, takich jak: regulacje (prawne, ale także samoregulacje różnych grup obywateli czy biznesu), współpraca, argumentowanie, debatowanie, badanie, kształtowanie pozytywnych bodźców do przyjmowania oczekiwanych postaw, wskaźniki efektywności działań, ewaluacja, ekspertyzy, instytucje (urzędy publiczne oraz sieci współpracy organizacji społecznych). Ponadto etnopolityka w państwach subregionu powinna uwzględniać trzy poziomy: 1) wybory programowe (policy choices), dokonywane przez polityków, urzędników i przedstawicieli innych ciał, które używają władzy publicznej do wpływania na życie obywateli; 2) wykonywanie programów publicznych (policy output), działania wykonywane przez uruchomienie całego zaplecza administracji i jej współpracowników; na tym poziomie rząd wydaje pieniądze, wdraża regulacje, wprowadza programy działań, zakłada czy likwiduje instytucje wykonawcze; 3) rezultaty działań publicznych (policy impact) i ich wpływ na życie obywateli (Guy Peters, 2004). Etnopolityka w państwach subregionu powinna obejmować pomysły na rozwiązanie problemów z jej zakresu, działania w tym zakresie, a także rezultaty i ich ocenę.

Dodać należy, że swoistym ograniczeniem w dalszych badaniach nad zarządzaniem etnopolityką w państwach subregionu (Białorusi, Mołdawii i Ukrainy) jest fakt, że mamy do czynienia ze wzrostem stopnia skomplikowania wielu problemów publicznych $w$ tym zakresie (m.in. tendencje separatystyczne, polityka językowa, polityka oświatowa, dyskryminacja na tle narodowościowym). Nie zmienia to faktu, że dalszych badań wymagają aspekty zarządzania etnopolityką w państwach subregionu związane z wymiarem jej wdrażania - fazą, która zaczyna się tuż po tym, gdy władza publiczna podjęła decyzje dotyczące realizacji konkretnej koncepcji działań wokół danego problemu etnicznego. Kluczowym wydaje się zbadanie, jak wiele na etapie implementacji zależy od zdolności do panowania 
nad czynnikami (uwarunkowaniami), które mają wpływ na efekty końcowe zarządzania etnopolityką na Białorusi, w Mołdawii i na Ukrainie. Istotnym jest także, aby badać związki etnopolityki z innymi politykami szczegółowymi w państwach subregionu i ich wpływ na kondycję polityczną i gospodarczą państw Europy Wschodniej.

\section{LITERATURA}

Abdulatipov, R. (2004). Etnopolitologiâ. Moskva-St. Peterburg: GMU.

Bajor, P. (2014). „Operacja” Krym - aneksja półwyspu i jej konsekwencje, Rocznik Instytutu Europy Środkowo-Wschodniej, 2, 37-55.

Bodio, T. (2010). Przywództwo, elity i transformacje w krajach WNP. Problemy metodologii badań. t. 1. Warszawa: ASPRA-JR.

Bodio, T., Jakubowski, W. (2010). Przywództwo i elity polityczne w krajach WNP. 2. Warszawa: ASPRA-JR.

Całus, K. (2016). Państwo niedokończone. 25 lat mołdawskiej niepodległości. Warszawa: OSW.

Guboglo, M. (2003). Identifikaciâ identicnosti. Etnosociologiceskie ocerki. Moskva: GMU.

Guy Peters, B. (2004). American Public Policy. Promise and Performace. Pittsburg: CQPres.

Hnatiuk, O. (2003). Pożegnanie z imperium. Ukraińskie dyskusje o tożsamości. Lublin: Wydawnictwo UMCS.

Jakubowski, A. (2018). Uwarunkowania konfliktów etnopolitycznych w państwach wielonarodowościowych. Środkowoeuropejskie Studia Polityczne, 1, 5-22.

Jansons, A. (2003). Ethnopolics in Latvia: Ethnopolitical Activities of State Institutions and Non-governmental Organisations and their Influence on the Social Integration Process. Washington: Ethnicity Studies.

Kellas, J.G. (1998). The Politics of Nationalism and Ethnicity. London: Palgrave Macmillan.

Kubaczyk, T., Majchrzak, A., Żyła, M. (2018). Mniejszości narodowe i etniczne w politykach bezpieczeństwa państw subregionu Europy Środkowej i Wschodniej. Państwa obszaru WNP. Warszawa: Akademia Sztuki Wojennej.

Miazga, A., Dybcio, M. (2001). Polacy na Białorusi - поляки в Беларуси. Warszawa: Stowarzyszenie "Wspólnota Polska".

Nacional'nyj sostav naseleniâ 2009 (2009). Pozyskano 12 sierpnia 2019 z www.census.belstat.gov.by/pdf/BOOK-ru-RU.pdf.

Nacional'nyj sostav naseleniâ Ukrainy 2001 (2001). Pozyskano 15 sierpnia 2019 z www http://2001.ukrcensus.gov.ua/rus/results/general/nationality.

Nacional'nyj statičeskij komitet Respubliki Belarus' (2019). Pozyskano 15 sierpnia 2019 z www.belstat.gov.by/ofitsialnaya-statistika/solialnaya-sfera/naselenie-i-migratsiya/naselenie.

Posner, D.N. (2005). Institutions and ethnicpolitics in Africa. Cambridge: University Press.

Radzik, R. (2009). Kulturowo-cywilizacyjna tożsamość społeczeństwa Białorusi. W I. Topolski (Red.), Białoruś w stosunkach międzynarodowych (ss. 39-75). Lublin: Wydawnictwo UMCS.

Recensamant.statistica 2014 (2014). Pozyskano 15 sierpnia 2019 z www.recensamant.statistica.md/ru/dissemination/person.

Rothschild, J. (1981). Ethnopolitics: a Conteptual Framework. New York: Columbia University Press.

Shypka, N. (2015). Analiza porównawcza specyfiki tworzenia i działalności organizacji mniejszości narodowych i etnicznych współczesnej Polski i Ukrainy. W H. Chałupczak, R. Zenderowski, E. 
Pogorzała, T. Browarek (Red.), Polityka etniczna. Teorie, koncepcje, wyzwania (ss. 659-666). Lublin: Wydawnictwo UMCS.

Tavadov, G. (2004). Etnologia. Moskva: GMU.

Toščcenko, Ž. (1993). Etnokratiâ: istoriâ i sovremennost'. Moskva: GMU.

Wierzbicki, A. (2008). Etnopolityka w Azji Centralnej. Warszawa: Elipsa.

Wierzbicki, A. (2014). Etniczność i narody w Europie i Azji Centralnej. Perspektywa teoretyczna i egzemplifikacyjna. Wydawnictwo Uniwersytetu Warszawskiego, Warszawa: ASPRA-JR.

Wierzbicki, A. (2015). Genetyczno-kulturowe podstawy etnopolityki. Perspektywa etnonacjonalistyczna. W H. Chałupczak, R. Zenderowski, E. Pogorzała, T. Browarek (Red.), Polityka etniczna. Teorie, koncepcje, wyzwania (ss. 51-69). Lublin: Wydawnictwo UMCS.

Wierzbicki, A., Karolak-Michalska, M. (2016). Mniejszość rosyjska w etnopolityce państw Europy Wschodniej i Azji Centralnej. Warszawa: WUW.

Zenderowski, R., Chałupczak, H., Baluk, W. (2015). Polityka etniczna: próba teoretycznej konceptualizacji. W H. Chałupczak, R. Zenderowski, E. Pogorzała, T. Browarek (Red.), Polityka etniczna. Teorie, koncepcje, wyzwania (ss. 23-96). Lublin: Wydawnictwo UMCS. 


\section{Tytuł i abstrakt w języku angielskim}

\section{The main determinants of ethno-political governance in the Eastern European countries}

The article presents the issue of conditions of ethno-political management in Eastern European countries. In the first part of the article the author explains what ethno-politics is, in the second part shows the key determinants of national policy in the subregion countries, indicating among them ethno-demographic, cultural, legal, ethno-political and multilateral conditions. In the final remarks, concludes that ignoring the above determinants makes it difficult to effectively plan, organize and control the processes of ethno-political management. The disregard of the above conditions by the state authorities in the subregion during the formulation of ethno-political objectives by the state on the one hand results in the ineffectiveness of the national policy, on the other hand it promotes the emergence of ethnic tensions and conflicts, thus threatening the security of individual states (especially Moldova and Ukraine), and consequently the entire subregion.

Keywords: $\quad \begin{aligned} & \text { ethnopolitcs; security threat; post-Soviet area; Eastern Europe; ethnopolitical } \\ & \text { processes }\end{aligned}$ JEL codes: $\quad$ F52, F53, J71

\section{Autor}

\section{Magdalena Karolak-Michalska}

Doktor nauk o polityce (2011), absolwentka Wydziału Dziennikarstwa i Nauk Politycznych Uniwersytetu Warszawskiego, autorka ok. 60 artykułów naukowych z zakresu etnopolityki. Absolwentka Wydziału Nauk o Wychowaniu Uniwersytetu Łódzkiego (studia podyplomowe psychologia zarządzania, 2015), a także Akademii Humanistyczno-Ekonomicznej w Łodzi (studia podyplomowe z zakresu doradztwa zawodowego, 2019). Adiunkt w Społecznej Akademii Nauk w Warszawie, wieloletni wykładowca akademicki na kierunkach stosunki międzynarodowe i zarządzanie.

Adres do korespondencji: Dr Magdalena Karolak-Michalska, Społeczna Akademia Nauk w Łodzi, ul. Łucka 11, 00-001 Warszawa, e-mail: mkarolak@spoleczna.pl

ORCID (1) http://orcid.org/0000-0002-3282-654X

\section{Prawa autorskie}

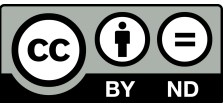

Publikacja została wydana przez Uniwersytet Ekonomiczny w Krakowie
Ten artykuł został opublikowany na warunkach Creative Commons

Uznanie autorstwa - Bez utworów zależnych (CC BY-ND 4.0 License) http://creativecommons.org/licenses/by-nd/4.0/ 
